boy, in demonstrating geometrical propositions, was not the least put about with the reversal of the diagram. He afterwards turned out a clever pattern-designer.

James SHaW.

\section{The Age of the Wealden.}

Is a letter in Nature for March 12, Prof. Marsh calls attention to the evidence of the vertebrate fauna of the Wealden rocks as being in favour of including that series in the Jurassic system.

It may be of interest to add that a recent examination of an exceedingly rich collection of fossil plants obtained by $\mathrm{Mr}$. Rufford from the Wealden rocks near Hastings, and now in the British Museum, leads very decidedly to the same conclusion. Between the Wealden flora of the South of England, in which no traces of undoubted Angiosperms have so far been found, and the typical Jurassic plants from the Yorkshire coast, there is a very close resemblance.

Cambridge, March 16.

The Stress in Magnetised Iron.

DR. CHREE will meet, I think, with general support in his opposition to the view that there is of necessity, or even usually, an actual stress in a magnetised rod tending to shorten it; but in maintaining, as I understand him to do, the opposite view that the magnetic tension along the lines of force is necessarily accompanied by a mechanical stress of pull and the associated extension, he appears to me to be on more disputable ground. Dr. Chree's conception of the Maxwell distribution of stress seems, if I may venture to say so, to be too materialistic. What Maxwell really showed, of course, was that such a distribution would produce on every element of matter in the field the mechanical force which it was known actually to experience. It was not suggested, however, that these stresses were to be considered as transmitted by the matter by virtue of its mechanical properties, indeed this could clearly not be the case where the matter was liquid or gaseous ; and so there are no grounds for supposing that the matter would exhibit strains directly associated with these stresses. The stresses, in fact, must be considered as transmitted by the ether which pervades the field, and it is in the ether that the associated strains are to be looked for.

If, however, we turn our attention from the ether to the matter in the field, and remember that certain portions of this matter will in general be experiencing mechanical forces, we see that if its equilibrium is to be maintained a suitable system of mechanical stresses and the associated strains must be set up in it.

In the case considered by Dr. Chree in his letter to NATURE, published on January 23, it is plain that if $\mathrm{AA}^{\prime}$ and $\mathrm{BB}^{\prime}$ are airgaps, and are not filled up with a material capable of offering resistance to longitudinal compression, the portions $\mathrm{A}^{\prime}$ and $\mathrm{B}^{\prime}$ of the bar must be held or fixed in some way if there is to be equilibrium. This was pointed out by Prof. Ewing, but Dr. Chree does not seem to have appreciated its significance, and his disregard of the external forces required for this purpose is responsible for the apparent discontinuity to which he refers in his second letter. If $\mathbf{A}^{\prime}$ and $\mathrm{B}^{\prime}$, with these forces applied to them, are allowed to move up to $\mathrm{A}$ and $\mathrm{B}$ so as to close up the air-gaps, we pass without discontinuity to the case of a magnetised rod under external pull, and thus in a state of mechanical tensile stress and elongation. If now we consider these external forces to be gradually diminished to zero, and suppose that the question is not complicated by end effects at the outer ends of $\mathrm{A}^{\prime}$ and $\mathrm{B}^{\prime}$ (as it will be in the case of a straight rod unless external forces are kept applied at these ends), the mechanical tensile stress and elongation will diminish to zero also, and we have passed without discontinuity from Dr. Chree's result to Prof. Ewing's.

That Dr. Chree has obtained the correct result for the special case which he investigates, appears from the following considerations. Assuming that $\mathrm{AA}^{\prime}$ and $\mathrm{BB}^{\prime}$ are equal air-gaps, and that $\mathrm{A}^{\prime}$ and $\mathrm{B}^{\prime}$ are fixed, $\mathrm{AB}$ will be in equilibrium. The Maxwell distribution of stress gives equal mechanical forces on the surfaces $\mathrm{A}$ and $\mathrm{B}$ directed outwards, and consequently there will be tensile mechanical stress in $\mathrm{AB}$ with its associated extension. In this case, therefore, there is actual elongation of the metal in the direction of the lines of force. In the case of an endless ring, however, the Maxwell distribution of stress gives no mechanical force, and no mechanical stresses with associated strains will be set up. This is the case considered by Prof. Ewing, who obtained the same result. I must confess that I do not follow Dr. Chree's objections to Prof. Ewing's reasoning on this point. The mechanical stresses must be such that every portion of the ring is in equilibrium. Prof. Ewing does not complain that tensile stress in a ring is unimaginable, but that it does not comply with this condition. If Dr. Chree will reconsider his reference to the case of a rotating anchor ring, he will admit, I think, that as every element of such a body is not in equilibrium, but in accelerated motion, the fact that tensile stress can and does exist in it is not relevant.

As a further illustration of the variety of the mechanical actions which may accompany the Maxwell distribution of stress, we may consider the case of two sheets of tinfoil placed against opposite faces of a plate of glass and maintained at different potentials. It is readily seen that in this case the glass undergoes a mechanical stress of compression and the associated strain of shortening in the direction of the lines of electrostatic force, though the Maxwell stress in this direction is a tension. L. R. WilberforCe

Cavendish Laboratory, Cambridge, February 26.

\section{RECENT WORK OF THE GEOLOGICAL SURVEY OF THE UNITED STATES.}

II.

SINCE Gilbert (in I887) published his classical monograph on the geology of the Henry Mountains, in which he gave to the world for the first time a clear and connected account of the nature and occurrence of Laccolites, we have waited many years for further original work on this type of physical structure in America. A study of the writings of Peale, and of the exquisite panoramic drawings of Holmes, made it abundantly clear that laccolitic masses must be frequent in the United States. Mr. Whitman Cross has now collected a number of instances from Colorado, Arizona, and $\mathrm{Utah}^{2}$ He has remarked on their structure so far as it has been made out by these observers, by Emmons, and by himself, given a description of the characters of the rock of which the laccolites consist, and offered some remarks on the general theory of laccolitic structure.

The theory has not been quite so fertile in results as might have been expected from the clear-cut nature of Gilbert's brilliant piece of work; nevertheless the author is able to show that, although Reyer refuses to accept the facts on which the theory is based, Suess, on the other hand, reproduced the illustrations, summarised the results of Gilbert, Peale, and Holmes, and applied them to European and other examples, while Neumayr added further arguments in favour of the intrusive nature of the Henry Mountain rocks themselves. It may be pointed out here that the existence of laccolites has been taken almost for granted by many British authors (not referred to by Cross), such as Kinahan, Geikie, Harker, Marr, and others, and that in one case at least a numerous group of laccolites has been described, and proof given that the igneous masses are conformably underlain and overlain by sediments. ${ }^{3}$ The abstract of this paper, all that was published for many years, also anticipates some of the conclusions independently reached by Mr. Cross.

The familiar Henry Mountains are first described, then the West Elk Mountains to which attention was drawn by Peale, and in succession the San Miguel, La Plata, Carriso, El Late, Abago, and La Sal Mountains. All these are either on the verge of the great plateau, being thus geographically outliers of the Colorado Mountains, or they are isolated groups on the plateau itself. They are groups of laccolites intruded into nearly horizontal strata probably at about the same period-in Tertiary

1 Continued from page 44 .

2 "Fourteenth Annual Report of the Geological Survey of the United States," I892-93. (1894.)

3 "Report of the British Association," I 886.

No. I 377 , voL. 53] 
time, as they pierce rocks of Cretaceous age. The Mosquito Range of central Colorado, and the Ten-Mile district to the west of it, were studied by Jacob and Emmons, and in these areas intrusive rocks of the same composition occur as laccolites, sills, and dykes in more ancient rocks, and even in the fundamental Archæan complex. A few other cases are referred to.

The study of these examples reveals the fact that the theory has received several important accessions, and even some modifications. The laccolite is beginning to lose the familiar mushroom shape which, with its central stalk, has done much to cause incredulity; we find, instead, excentric dykes and pipes, complex groups of dykes, even sheets and dykes in suspicious proximity to important faults, indicated as the feeders of the lensshaped masses of igneous material; this gives much more of structural verisimilitude to the type. Again the masses are shown to be more often irregular or unsymmetrical in outline, faults as well as folds give easement to the lifted cover, the so-called pine-tree laccolite, or group of anastomosing sheets is not infrequent; bunches of laccolities irregularly intruded into yielding shales take the place of the single "stone cistern," and the laccolite is sometimes shown to cross the strata both above and below. In addition to formal sections, many of the beautiful outline and panoramic sketches of Holmes are reproduced; these are drawn with such a wonderful feeling for the run of the country, that the igneous structure can often be made out from them alone. In fact, so much has been made out of what material has been already got together, that we feel bound to express a hope that selected examples of the group will shortly be mapped out in detail by the skilled stratigraphers of the Survey, in order to ascertain in such a favourably exposed region what is the precise relation of laccolitic groups to the folding of rocks, and the exact part played by them in tectonic history.

It is a remarkable fact that the rock in the laccolites is almost uniform in character. It is called a porphyrite, and contains phenocrysts of either hornblende, augite, hypersthene, biotite, quartz, and felspar, or several of these in a holocrystalline but compact matrix of quartz and orthoclase. The silica percentage, omitting one doubtful and exceptional type, varies from $69-55$, but is generally about 63 , and the proportion of potash to soda, $2 \cdot 5-4$, is fairly constant. The porphyritic crystals, chiefly intratelluric in origin, have increased in size after the intrusion of the rock, and it is thought that the phenocrysts of orthoclase, which occasionally occur, have been completely formed after intrusion. Gilbert's hypothesis, that the laccolitic structure is determined by conditions of density, is not accepted in its entirety, the author quoting with approval Dana's criticism that Gilbert's explanation "appears to be complete without reference to this difference of density. With so powerful a forced movement as the facts, if they are rightly interpreted, show to have existed, no other cause could be needed for a flow to the surface in the case of an open channel, or for a flow to any level in the strata at which a fissure might terminate; and this is true, whether the lava be light or heavy." Hints are given throughout the paper that orographic movements may often have had a determining effect in the localisation of laccolites, a result already reached by some observers in Britain.

An exceptionally interesting piece of experimental work is contained in Mr. B. Willis's "Mechanics of Appalachian Structure." 1 A long series of experiments was undertaken, and is here illustrated by twenty-one large plates, while a number of maps, sections, and photographs from the Appalachian ground are of use to compare with the experimental results. In addition to the usual types of folds defined by the opposed dips, we have a classification

I Thirteenth Annual Report of the Geological Survey of the United States, r891-92. (1893.)

$$
\text { NO. I } 377 \text {, vOL. 53] }
$$

according to ccmpression into open, closed, and carinate or isoclinal folds. In the Appalachians the following districts are recognised : the district of (I) open folding, (2). closed folding, (3) folding with faulting, (4) folding with schistosity. One of the great questions to which the observer is led is this: As the "conditions antecedent to deformation were the result of sedimentation, does the distribution of strata afford an answer to the questions raised ?" To investigate this problem a mixture of beeswax with plaster of Paris and Venice turpentine of varying consistency was used, in thin, large sheets, resting on a plastic support, and covered by shot to act as a load. This was contorted by lateral pressure applied by means of a slow-motion screw. One of the first results to come out was that any slight dip in the layers of material was usually sufficient to initiate a fold. "In strata under load an anticline arises along the line of initial dip, when a thrust, sufficiently powerful to raise the load, is transmitted: by a competent stratum. The resulting anticline supports the load as an arch, and, being adequate to that duty, it may be called a competent structure." From this it follows that the size of an anticline depends on the competency of the stratum and inversely on the load. Some evidence has been obtained in the field that the initial dips in the Appalachians have influenced the folding. An interesting by-product of the experiments is the fissuring of tissue-paper placed between the layers; along lines at right angles to the wrinkles. The work then goes on to consider the packing of folds and the formation of faults. The plates illustrate the successive steps of each experiment of which the details are thought worthy of publication.

Owing to the small scale of the maps and to the rapidity with which surveying is carried out, it is often necessary to generalise the geological as well as the topographical features expressed on the maps, when it is desired to bring out important tectonic characters. This is pointed out by Prof. Iddings, and atoned for by the conscientious completeness with which he has worked out the petrological affinities of the intrusive and eruptive rocks of Electric Peak and Sepulchre Mountain. ${ }^{1}$ Separated now by a great fault, with a downthrow to the north-east, along: which a valley has been excavated, one of these massesSepulchre Mountain-was once situated almost directly over the other. Sepulchre Mountain is made up of volcanic accumulations, andesitic and rhyolitic breccias and lava-flows, with dykes and other eruptive volcanic products; Electric Peak consists of intrusive sheets, dykes, and "stocks" of porphyrite and diorite corresponding in a general way in composition with the rocks first mentioned, but differing in their coarser texture and more plutonic aspect. The relative date of the members. of the intrusive series can be made out and paralleled stage by stage with the volcanic products, so as to make it clear that we have here side by side the surface and the deep-seated products of one volcano. This is expressed. in tabular form, as follows :-

$$
\text { Electric Peak. }
$$

(a) Intrusive sheets of porphyrite.

(b) Intrusion of dyke and stock rocks in the following order :-

Pyroxene-porphyrite to pyroxene- and hornblende-diorites.

Hornblende - biotite-diorites and porphyrites.

Quartz - biotite - dioriteporphyrite.

Such a parallelism cannot be the result of an accident, and it affords a most useful opportunity for the study of the relations of deep-seated and surface products; of this

1 Twelfth Annual Report of the Geological Survey of the United Stater, I890.91. (1892.) (b) Andesitic breccias and dykes in the following order :-

Pyroxene-andesites to pyroxene - hornblendeandesites.

Hornblende - biotites-andesites. Dacites. 
chance Prof. Iddings has not been slow to take the fullest advantage. The author does not use the word porphyrite in the sense of an altered or ancient andesite, but applies it to "medium-grained porphyritic rocks that occupy an intermediate position between the coarsely granular diorites and gabbros and the microlitic or glassy andesites." In describing the diorites, he gives a plate of examples of the intergrowth of such minerals as hornblende, biotite, augite, and hypersthene. The whole of the plutonic rocks are compared together as to structure and chemical composition, and shown to form a connected and overlapping series. Similar comparisons are effected between the volcanic products of Sepulchre Mountain. Mr. Iddings points out that it is impossible to trace any actual transition through stock and dyke rocks into the corresponding eruptive rocks, for the reason that they are often cut asunder while the volcano is in activity, and because the pipe is invaded by each magma in turn, the last alone remaining there to solidify, unless little patches of necessarily altered previous types happen by accident to survive.

In the nincteenth monograph, Messrs. Irving and Van Hise treat of the Penokee iron-bearing series of Michigan and Wisconsin. This is a monoclinal series of rocks dipping northwards off a mass of crystalline rocks which lie to the south, and extending a distance of eighty miles along their strike. The "Southern Complex" is a mass of schists of eruptive origin, with masses of granite intruding into them. Resting unconformably on this complex, comes a thin series of cherty limestones ( 300 feet) of aqueous origin, but whether chemical or organic is not known, and unconformably again on that, the quartzslate ( $500 \mathrm{feet}$ ). The iron-bearing member ( 800 feet) in its least altered state is a water-deposited cherty iron carbonate, which can be seen to grade into ferruginous slates, these into ferruginous cherts with concretionary and brecciated structures, and these again into actinolitic slates containing much magnetite. This rock is penetrated by diabase dykes which, when intruded, appear to have been vertical, while the beds were horizontal It results from this that, now both are tilted, $V$-shaped areas occur defined by the upper quartzite of the quartzslate on the one hand, and the dykes on the other. it is in the apices of these V's, that the iron ore is now concentrated, the original rock being rendered very poor in ferruginous constituents, which have been re-deposited in the ore masses as hrematite. In the area east of Gogebic Lake, the regular succession is disturbed by volcanic accumulations and greenstone conglomerates. The Upper Slate member (I2,00o feet) rests on the ironbearing rocks, but it does not extend quite so far as they do. The southern complex is placed in the Archæan system, the overlying beds into the Algonkian; these are covered by the Keweenawan series, after which the rocks received their monoclinal tilting; finally, the Eastern Sandstone was unconformably deposited on them all. The work is illustrated by a large series of illustrations of the microscopic structure of igneous and sedimentary rocks, and by maps and sections.

Mr. Walcott ${ }^{1}$ gives an admirably illustrated account of the igneous rocks of the Unkar terrane, a group which underlies the Tonto Sandstone in the district of the Grand Cañon of the Colorado, and has been variously referred to the Algonkian, the Cambrian, and the Silurian by himself and other authors. The presence of a wellmarked Middle Cambrian fauna in the upper part, and a strong unconformity at the base of the Tonto Sandstone, are sufficient in the opinion of the author to. warrant our considering the Unkar beds as Pre-Cambrian, and correlating them with part of the Algonkian succession. The upper part of the Chuar terrane, which immediately uncerlies the Cambrian rocks, consists of

\footnotetext{
1 Fourteenth Annual Report of the Geological Survey of the United States, 1892-93. (r894.)
}

NO. I 377 , voL. 53]
1700 feet of shales and sandstone, with 138 feet of limestone ; the lower division of this terrane has 3420 feet of similar rocks, with 147 feet of limestone of a rather different type. Two of the limestones are spoken of as Stromatopora limestones, and they contain an organism which is probably a species of Cryptozoon.

The Unkar terrane which underlies that last described, is 6830 feet thick ; there are magnesian limestones at the top, followed by lava beds 800 to rooo feet thick, then sandstones and another lava bed from 80 to I 80 feet thick on a limestone and conglomerate, which rest unconformably on the Vishnu schist, and the gneisses and schists of the Archæan System. The igneous rocks were probably submarine flows poured out from fissure eruptions, the dykes of which are still visible in the walls of the cañon, during a slow subsidence when beds of sandstone and shale were interleaved with the volcanic products.

Mr. Iddings, who contributes an appendix, describes the lavas as olivine-basalts sometimes fresh but more usually altered, the felspar passing into saussurite, the pyroxene to chlorite, and the olivine to serpentine and other products. When the original structure is well preserved, it does not differ much from that of the Tertiary lavas of the same area. The ground-mass of the basalts is usually microcrystalline, but in the middle of thick sheets it becomes ophitic, while the upper and under parts are scoriaceous and amygdaloidal.

In that lucid style for which his work is well known, Mr. Walcott ${ }^{1}$ sketches out the physical history of the North American continent during Cambrian time. He shows that Dana's idea of the existence of a V-shaped skeleton, about which Palæozoic sediments accreted, is in the main correct, but he is able to fill in a number of details which were of necessity left blank by that author. The underlying massif is composed of Algonkian rocks resting unconformably on those of Archiean age; its rocks were tilted and uplifted into a land area, which Walcott proposes to call the Algonkian continent, and which was of wider extent than any land in this position until Mesozoic time. This continent consisted of four chief parts: ( 1 ) the $V$-shaped mass running parallel to the outlines of Hudson Bay, and possibly extending in a shield-like area to Texas and the Colorado River; (2) a Palceo-Appalachian range, with sub-parallel chains and spurs ; (3) a Palæo-Rocky Mountain mass; and (4) a Paleo-Sierra Nevada mass. Sedimentation took place in all the seas defined by these land areas in early Cambrian (Olenellus) times; that is to say, in (I) the Atlantic Coast Province east of the Palæo-Appalachians ; (2) the narrow sea extending from Labrador to Alabama ; and (3) on the west side of the great V-shaped mass.

In Middle Cambrian times there was little change in the areas of deposition, except that partial barriers erected along the line of the Appalachians only allowed a small part of the typical (Paradoxides) fauna to penetrate westwards from the Atlantic basin. Strongly defined zoological provinces evidently existed in Middle Cambrian time, as proved by the study of the fauna of this period to the west.

Steadfast depression then began, and the Upper Cambrian Sea carried its sediments over the whole of the great south central region, including almost the whole of the United States as far north as Chicago, and from the Sierra Nevada to the Appalachians. The Appalachian barrier was, however, strengthened so that the fauna of the Atlantic coast in Upper Cambrian times was related to that of Europe, and quite distinct from that of the Central States. This great depression brought on the limestone deposits of the Ordovician system. The memoir is illustrated by several important geological and palæo-geographical maps.

1 Twelfth Annual Report of the Geological Survey of the United States, 1890-9t. (r891.) 
Volume xxiii. (1894) of the Monographs of the Survey is devoted to the geology of the Green Mountains in Massachusetts, by Messrs. Pumpelly, Wolff, and Dale. This district of Palæozoic rocks is complicated by two circumstances ; in the first place, the limestones of Greylock Mountain appear to pass shoreward into the sandy and shaly beds of Hoosac Mountain to the west, and in the second place, metamorphism has proceeded much further at the western end of the series. Resting on the Stamford gneiss of Pre-Cambrian age comes the coarse gneiss of the east side of Hoosac Mountain, which is traceable into coarse conglomerate, "white gneiss," and quartzite as we pass towards the north and west. The lower part of the Hoosac schist passes similarly through the calcareous schist of the Hoosac Tunnel into the Stockbridge limestone. The upper part of this schist is perhaps to be correlated with the Berkshire and Greylock schist series, which are separated by the Bellowspipe limestone. The rocks are over-folded and faulted as well as metamorphosed, but patient mapping has unravelled the complex structure, and enabled the writers to assign the Stamford gneiss to the Pre-Cambrian System, the Vermont Formation and the Lower Stockbridge limestone to the Cambrian, and other rocks mentioned to the Silurian System. Much credit is due to the authors, and their assistants in the field, for such a careful and detailed piece of work, in which everything has been subordinated to the elucidation and presentation of the facts.

Mr. T. Nelson Dale, ${ }^{1}$ in his account of the Renselaer Grit Plateau of New York, thinks that the grit occupies a place (probably unconformably) above the Hudson River shales, which are themselves equivalent to the Berkshire schists, but in a less altered condition, and in their turn rest on the Stockbridge limestone. The upper part of this last rock, which is crystalline and contains clastic grains of quartz and felspar, yields fossils of Trenton, Chazy, and Calciferous age, but its lower part represents much more ancient time, as it contains Cambrian fossils. and is thought to be the equivalent of the Olenellus limestone, which, further east, rests on Archrean rocks.

The grit itself is a coarse graywacké containing some secondary minerals, and interbedded with red slates and phyllites. On the west side of the syncline it is underlain by shales and phyllites of the Hudson River group, which pass towards the east into muscovite and chlorite schists which contain ottrelite, tourmaline, and more rarely albite. A map, coloured sections, some admirable photographs, and figures of rock-structure, illustrate the paper, which appears to be an excellent piece of minute stratigraphical and petrological work.

To the same author we owe an account of the structure of the ridge between the Taconic and Green Mountains in Vermont. ${ }^{2}$ This consists of an anticline of lower Cambrian rocks overlain by Stockbridge limestone and Berkshire schist. The anticline is broken by a "keystone" fault, a thrust-plane, and one or two minor disturbances. Mr. Dale also gives another interpretation to the structure of Monument Mountain ${ }^{3}$ differing from those advanced by Dana. He regards it as a synclinorium somewhat disturbed by faulting. The rocks involved are the Stockbridge limestone, the Berkshire schist, quartzite, and Silurian rocks.

Mr. A. Keith ${ }^{4}$ gives an account of the Catoctin Belt, a region which is roughly the mountain tract of Maryland and Virginia, a geological continuation to the north-east of the Appalachian flexure system. The lowest rocks are relegated to the Algonkian System, and consist of a flow of diabase lava, followed by others of quartz-porphyry and andesite, and by intrusions of granite ; these, again, are

1 Thirteenth Annual Report of the Geological Survey of the United States, 1891-92. (1893.)

2 Fourteenth Annual Report of the Geological Survey of the United States, 1892-93. (1894.)

4 Ibid. succeeded by other diabase flows: the diabases are now converted into the Catoctin schists. The overlying Cambrian rocks are divided into four, and the Silurian into three, divisions. A map of the whole area is given, and, in describing both igneous and sedimentary rocks, smaller scale maps are used to show variations in composition and structure. Lines are drawn on these maps through those points where a given band of rock has the same thickness (isometric or isodiametric lines, as they have been called), and by this means a very good idea of variation in thickness is given. Fossils found in the Cambrian rocks have been of the utmost use, not only in indicating the general age of the rocks, but also in making out the general succession, and in unravelling difficult bits of stratigraphy. The upper part of the Shenandoah limestone contains Silurian (? Ordovician) fossils, but its lower part yields lower Cambrian with some middle Cambrian forms. Above the representative of the Hudson River shales comes the Newark formation, of Jura-Trias age, which contains dykes and sills of diabase. The region underwent folding, thrusting, and metamorphism of Appalachian type before the Newark time, and subsequently was tilted and faulted on the monoclinal plan. It was planed down in Cretaccous times, and reduced to a base-level before the Lafayette period; certain portions which survived this second planing are delineated in a map. An interesting comparison is appended in which the amount of area planed down, and the amount of rock removed by different phases of denudation are used to obtain a rough estimate of the time elapsing during different parts of the Tertiary Period. This gives the following relative figures:Tertiary, I 34 ; Early Pleistocene, I ; Late Pleistocene, Recent, a small fraction.

Mr. C. S. Prosser's Bulletin on the Devonian Rocks of East Pennsylvania and New York ${ }^{1}$ is an admirable piece of detailed stratigraphy, in which the fossils have evidently been carefully collected and identified from each important horizon, so as to place on record a number of facts that enable detailed comparison to be made with the better-known sections of western and central New York. About 8000 feet of rock are shown, of which 500 belong to the lower, 2200 to the middle, and 5300 to the upper division of the system. The bulk of the fossils are of marine type, but some land plants were discovered.

In his paper on a Geological Reconnoissance in Northwest Wyoming, Mr. G. H. Eldridge ${ }^{2}$ gives a description of the great anticline of the Big Horn Mountains and the three basins lying east, west, and south of it respectively. The rocks belong to the Archrean, Cambrian, Silurian, Carboniferous, Triassic Cretaceous, and Eocene systems. The Palæozoic rocks appear to be conformable throughout, and there seems to be no break between them and those of Mesozoic age until the summit of the Laramie beds is reached; several breaks occur in the higher beds. Coal, a lignite of good quality, is found in the Laramie terrane, oil in the anticlines of Trias and Niobrara beds, building-stone everywhere, and gold in the north part of the Big Horn Mountains. The hot springs and agricultural qualities of the soils are described, and useful analyses of forty coals are appended.

An account of the economic geology of a portion of the main Appalachian coal-basin, and of an outlier called the Potomac field, is given by Mr. J. D. Weeks in the fourteenth annual report. ${ }^{3}$ The chief coals are the Pittsburg seam of the Upper Productive Measures, the Upper Freeport and Lower Kitanning seams of the Lower Measures, and the New River and Flat Top seam of the Pottsville conglomerate. A description of the measures and their coals is given, but some of the vertical sections

1 Bulletin of the United States Geological Survey. No. 120. (1894.) 2 Ibid., No. i r. (1894.)

3 Fourteenth Annual Report of the Geological Survey of the United States, 1892-93. (I894.)

NO. 1377 , vOL. 53$]$ 
are at first rather misleading, as one scale is employed for the measures; another and much larger one for the interbedded coal-seams. It is pointed out that in many cases it is not the only, nor indeed always the best, seam which is actually mined at any particular spot.

Passing to the west side of the continent, we have first to deal with the work of $\mathrm{Mr}$. H. W. Turner on the rocks of the Sierra Nevada. ${ }^{1}$ The older set of rocks, which contain auriferous veins, and are spoken of as the auriferous series, are much disturbed, and it is very difficult to make out their exact relations, particularly as they are bent into a series of isoclinal folds. Fortunately, however, many of the beds contain fossils, by the aid of which it may be possible eventually to unravel their structure. The following Systems appear to be represented: the Silurian, Carboniferous (three divisions), Jura-Trias (?), Trias (two divisions), and Upper Jurassic or Lower Cretaceous. The last, or Mariposa formation, appears to overlap the others, and sometimes to rest on Carboniferous beds; but the maps which express this fact are not easy to interpret. These older rocks contain beds of lava and ash at many horizons, with intrusive rocks of all types, from granulite and granodiorite (or quartz-mica-diorite) to peridotites and pyroxenites. The sediments are often highly metamorphosed, and, so far as we may judge by the nature of the minerals produced, such as andalusite and sillimanite, in all probability by thermal action.

The newer rocks include representatives of the Upper Cretaceous, Eocene, Miocene, Neocene, Pliocene, and Pleistocene Systems. The Neocene rocks are the auriferous river gravels, and the Pliocene beds are shore gravels, which sometimes contain gold. These are associated with flows of rhyolite, basalt, and andesite of various types, and with great sheets of breccia and tuff derived from them. The Sierra appears to have received its chief uplift after the deposit of the Mariposa slates, and then to have been planed down in both Cretaceous and Tertiary times to an almost flat surface, which is in places preserved under the Tertiary volcanic accumulations. Late in Tertiary time came another great uplift, accompanied by faulting.

A very useful piece of economic work is that by Mr. W. Lindgren on the gold-silver veins of Ophir, California. $^{2}$ The country-rock consists of an area of schistose amphibolites towards the north-east, into which a mass of granodiorite was intruded at some date subsequent to the formation of the Mariposa slates. The amphibolites contain lath-shaped felspars set in hornblende, chlorite, and feIspar, and they have evidently been derived from the alteration of diabases; the grandiorite consists of quartz, potash and soda-lime felspar, biotite, and hornblende. Dykes of amphibolite and the auriferous veins traverse both rocks, and the latter group themselves into four systems: a north-west and south-east set parallel to the strike of the schists, another set running north and south, a third west $10^{\circ}$ north, and a fourth east $20^{\circ}$ north. To some extent all the quartz veins bear precious metal, but the ore is concentrated into pockets and chimneys. While the veins in the granodiorite are more extensive, of low grade and rich in silver, those in the amphibolite are of smaller extent in depth and width, but richer in gold, poorer in silver, and frequently reduced to mere pockets. The amphibolite is in places impregnated with pyrites, and it is well known that where the veins cross these "iron belts" they become especially rich in ore. The minerals include native gold, silver, and copper, electrum, horn-silver, and many sulphides. Both types of rock are much altered along the walls of the veins, the amphibolite passing into an aggregate of carbonates, white mica, and pyrites.

The geology of the Eureka district, Nevada, by Mr. A.

1 Fourteenth Annual Report of the Geological Survey of the United States, I892-93. (I894.)

NO. 1377 , VOL. 53$]$
Hague, ${ }^{1}$ contains an appendix on the fossils by $\mathrm{Mr}$. Walcott, and another on the igneous rocks by Prof: Iddings. The work begins with a general description of the physical geography and geology, from which we gather that the following is the succession of the chief rocks of the district. The Cambrian rocks are 7700 feet thick, and are divided into the Prospect Mountain quartzite, the Prospect Mountain limestone, which contains an Olenellus fauna, the Secret Cañon shale, the Hamburg limestone with a Potsdam fauna in its lower and upper parts, and the Hamburg shale. The Silurian rocks are 5000 feet in thickness, made up of the Pogonip limestone with a Potsdam fauna at the base, then Chazy forms, and in the higher portion some of Trenton facies; the Eureka quartzite ; and the Lone Mountain limestone with Trenton and, possibly, some Niagara fossils. The Devonian system is 8000 feet thick, divided into the Nevada limestone and the White Pine shale. The Carboniferous Formation has four members, the Diamond Peak quartzite, the Lower Coal Measure linestone, the Weber conglomerate, and the Upper Coal Measure limestone. The chief feature about the Carboniferous rocks is the fact that there occurs a freshwater fauna at the base of the Lower Coal Measure limestone, and a mingling of Devonian, Lower Carboniferous, and Coal Measure species in a limestone overlying beds characterised by a pure Coal Measure fauna.

These sediments are penetrated by granites, graniteporphyries, and quartz-porphyry, and are overlain by immense quantities of Tertiary or later volcanic rocks. The great eruptions for the most part cover subsided regions; where a mountain block has been uplifted, they occur at its borders. The succession of eruptions seems to have been as follows: hornblende-andesite, hornblendemica-andesite, dacite, rhyolite, pyroxene-andesite, basalt. It is suggested that the original magma split up into two-one felspathic, the other pyroxenic; the felspathic eruptions become steadily more acid until rhyolite is reached, the pyroxenic eruptions more basic from andesite to basalt. The ore deposits are mainly of lead and iron rich in gold and silver. Originally deposited as sulphides, they have been oxidised by air and surface water. They occur in cavities in all the Cambrian, Silurian, and Devonian rocks except the great shale masses. One analysis gave 27.5 ounces of silver and $1 \cdot 5$ of gold to the ton.

Mr. Walcott's appendix includes a long list of fossils from all the beds. Mr. Iddings calls the granite an amphibole-granitite containing quartz, orthoclase, plagioclase, hornblende, and mica ; the granite-porphyry is the chilled-edge phase of the granite-magma, of which the quartz-porphyry is the final phase. In all the volcanic rocks "there is a marked similarity between the individual crystals of the same mineral species wherever they occur ... which links the various kinds of rocks together and suggests the possibility of a common source." The work is admirably illustrated by figures and photographs.

Mr. J. S. Diller gives an impressive picture of Tertiary denudation in his "Tertiary Revolution in the Topography of the Pacific Coast." 2 After the beds of the Shasta-Chico (Cretaceous) series were laid down, the country was planed down to a base-level. At the present time this "pene-plain" has an average maximum slope of $2^{\circ}$, which rises to $5^{\circ}$, and then somewhat rapidly up to $17^{\circ}$, on the flanks of the Klamath Mountains, a name used to designate the group which occurs at the junction of the Cascade range with the Coast range and the Sierra Nevada. The plain stretches across the head waters of the Sacramento River to the Sierra Nevada, and probably comes out at the other side of it in the

1 Monographs of the Geological Survey of the United States, vol. xx. (1892.)

${ }_{2}$ Fourteenth Annual Report of the Geological Survey of the United States, 1892-93. (1894.) 
interior of North-East California and the adjacent parts of Oregon, being covered in the interval by Tertiary volcanic products. The plain is cut on to the Chico series and older rocks, and there rest on it the Ione formation, probably equivalent to the auriferous gravels, the Tuscan tuff, and the Red Bluff Pleistocene beds. It is noteworthy that the plant remains in the oldest of these rocks are of low altitude and not mountain types. There was evidently much movement in post-Chico time, then came erosion during the Eocene, and finally new movement with some warping and deformation. As the Eocene base-level was perfected erosion became much slacker, and was chicfly effected by solution, so that there was left much insoluble and dense material, including quartz and gold, ready to be deposited in the auriferous gravel when the next movement supervened, making the slopes steeper and giving the streams fresh impetus.

Returning now to the east, we have a lengthy account, by Mr. W. J. McGee, of the Lafayette Formation. ${ }^{1}$ This writer has shown a remarkable adaptability in suiting his style to his subject, as he expresses it in the following sentence: "The history of development of the eastern land is recorded in nature in characters so grand that but a small part of a single one may be seen at once, so that the direct reading is difficult." The Coastal Plain of the United States is based on Cretaceous rocks, which are covered by the following rocks in order, the first having an uncomformable base : the Lignitic beds, the Claiborne and Meridian deposits, the VicksburgJackson or White Limestone, the Grand Gulf beds, the Lafayette formation, and the Columbia beds. From this succession the author makes out the chief oscillations and changes in physical geography undergone by the Atlantic slope and the Mississippi embayment. The age of the formation we are left to judge from the following enigmatical sentence. "If the Cenozoic be not made to include the Pleistocene, and if the age be then divided into equal portions called Eocene and Neocene, and if then the Neocene be divided into ten equal parts, the Lafayette period may be supposed to correspond with the eighth or, perhaps, with the seventh or the ninth of these parts." The work closes with an account of the material resources of the formation, soils, siliceous clays, gravel, and iron, followed by the history of events recorded in the rocks. Mr. McGee illustrates his paper with some excellent maps, and also contributes to the fourteenth Annual Report a geological map of the whole of the United States at present surveyed.

W. W. W.

\section{THE GAME FIELDS OF THE EASTERN TRANSVAAL.2}

$\mathrm{I}$ proceeding into the interior of Africa from almost any point on the eastern coast, the traveller passes over a low coastal plain to the foot of the scarp of a high plateau. This plateau is succeeded to the west by a still higher one, which is gained either by a second steep ascent or by a gradual slope. The existing river valleys and former earth-movements have in places interrupted this arrangement; but, notwithstanding a few such exceptions, it persists with remarkable uniformity from Abyssinia to Natal, where the dominant meridional geographical lines bend round into the east and west series that rules in Cape Colony. In the eastern Transvaal, this zonal arrangement of the country is well developed. Inland from Delagoa Bay is a tract of undulating lowland, ending at the foot of the Libombo Mountains,

1 Twelfth Annual Report of the Geological Survey of the United States, 1890-91. (I89I.)

"In Haunts of Wild Game. A Hunter-Naturalist's Wanderings from Kahlamba to Libombo." By Frederick Vaughan Kirby, F.Z.S. 8vo. Pp. $\mathrm{xvi}+567$. With map, portrait, $\times 6$ full-page and 24 smaller illustrations. (Edinburgh and London: Wm. Blackwood and Sons, 1896 .) which separate Swaziland and the Transvaal from Portuguese East Africa. Seventy miles further to the west is the parallel range of the Drakensberg or Kahlamba (to adopt the author's spelling of the name, which is usually written Quahlamba). Between these mountain ranges is a belt of bush-covered veldt. The Crocodile River (a tributary of the Komati) and the Olifants River flow from west to east across this belt, at a distance of about Ioo miles from one another. These, with the mountains, enclose a roughly quadrangular area, some 7000 square miles in extent, which is the favourite hunting-ground of Mr. F. V. Kirby. Small though this area is, it includes very varied types of country. To the west are the densely wooded eastern slopes of the Drakensberg, and part of the turf-clad plateaus or terraces beyond; to the east lies low country with sub-tropical vegetation, intervening between the Libombo Mountains and the Limpopo River.

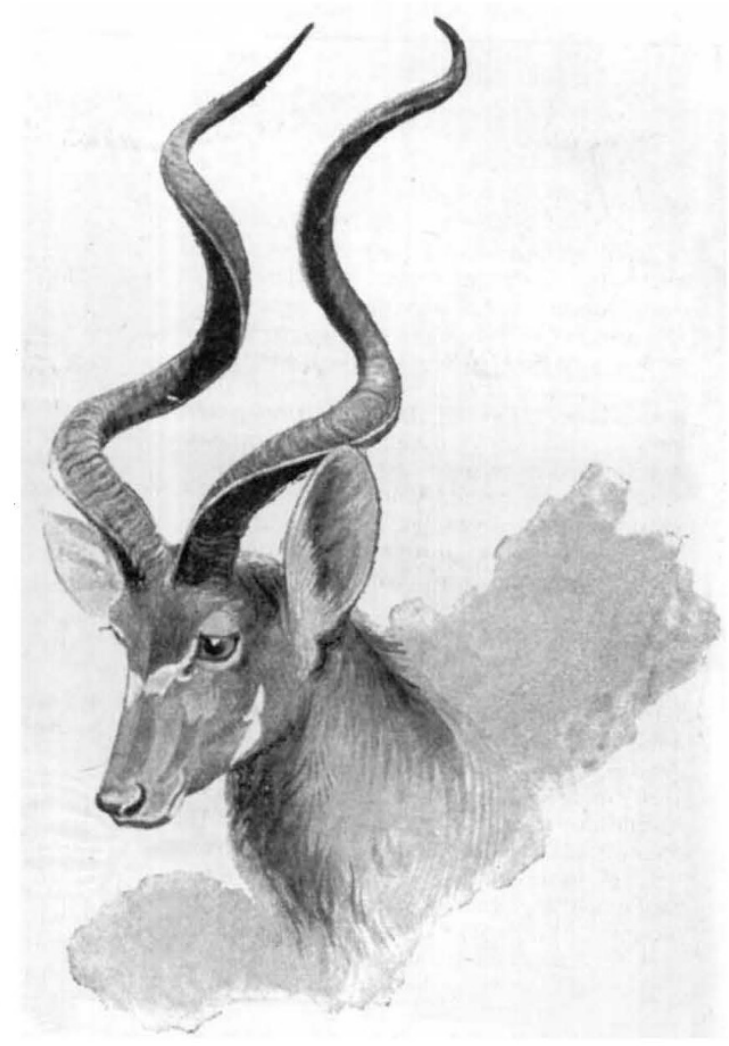

FiG. r.-A Head of the Great Kudu.

Most of the area consists of barren, scrub-covered plains known in this part of Africa as Bush-veldt, and near the equator as the Nyika. Most of this area was once rich in game. In the Bush-veldt lived the rhinoceros and buffalo, the sable and roan antelopes, the gnu, waterbuck, zebra and mpalla. The wooded foothills of the Drakensberg, or the "Kloof Country," was the home of the koodoo, the hill-leopard, the bush-buck, and the reedbuck. On the western plateau, or the "Krantz Country," in addition to some of the animals mentioned, lived the oribi and the mountain reed-buck.

This book relates the experience of nearly twenty years of hunting in this rich game country. The author tells his story in much better English than we are used to in books of sporting adventure. $\mathrm{He}$ is obviously not only a skilled sportsman, but a man with a keen eye for fine scenery, of literary tastes, and a careful and patient 